\title{
Permeable pavement used on sustainable drainage systems (SUDs): a synthetic review of recent literature
}

\author{
M. Marchioni \& G. Becciu \\ Department of Civil and Environmental Engineering, \\ Politecnico di Milano, Italy
}

\begin{abstract}
This literature review covers the role of permeable pavement on urban drainage and sustainability, and summarizes literature focusing on the system's general behavior and full scale tests. By allowing water to infiltrate its structure, the permeable pavement works on reducing runoff volume and improving water quality while still providing a useful area, comprising the main premises on sustainable urban drainage systems (SUDs). This solution is already well known, is commercially available and referred to in many municipality legislations. Analyzing the literature, it is possible to confirm the feasibility of the pavement, even though research is still required on specifics areas.
\end{abstract}

Keywords: permeable pavement, urban drainage, sustainability, SUDs.

\section{Introduction}

In 2010, the world's more developed regions, being all regions of Europe plus Northern America, Australia/New Zealand and Japan, presented an amount of urban population of $77.5 \%$ being estimated to reach $85.9 \%$ by 2050 (Heilig [1]). Urbanization growth impacts on watershed imperviousness and is directly linked to hydrological effects on streams. With the natural drainage impaired due to paved roads and the large number of buildings, stormwater runoff and its return to the water table becomes more difficult, resulting on runoff increase volume, peak flow and can eventually lead to floods, channel widening, habitat loss, erosion and streambed alteration (USEPA [2]). This situation is compounded by the "heat islands" effect where the higher temperatures in densely populated area ultimately enhances precipitation (Alves Filho and Ribeiro [3]). 
The urban drainage system is responsible for directing and controlling stormwater runoff, dispelling it from its generation, just transferring the runoff from one point to another downstream basin, acting on the effect and not the cause of increased runoff, which is the increase on impervious surfaces (Paulo [4]). However, this approach is becoming unsustainable facing the current urban growing and it becomes necessary to promote runoff volume reduction and treatment through solutions for retention, infiltration and runoff abatement (Paulo [4]). The philosophy behind these measures is to maintain the condition of drainage after developing the closest possible to the natural pre-development (Woods-Ballard et al. [5]). They are commonly referred as SUDs (sustainable drainage systems) (Woods-Ballard et al. [5]), BMPs (Stormwater Best Management Practice (Field and Tafuri [6]) or LID (Low-Impact Development stormwater drainage systems) (Elliott and Trowsdale [7]). The aim of these measures is to minimize the impacts of urbanization acting in quantity and quality of runoff and promote opportunities on amenities and biodiversity (Woods-Ballard et al. [5]). There are many practices that meet this new approach, such as permeable pavements, infiltration trenches, roofs reservoirs, detention reservoirs (Paulo [4]). To select a particular practice is necessary to consider urban factors, social, economic and environmental issues, including the drainage area, the infiltration capacity of the soil, groundwater level, land slope, area availability and the presence of sediments, among others (Paulo [8]).

Permeable pavements act on runoff volume reduction through reduction of impervious areas and by disconnecting the discharge from the municipal drainage system and is described as an infiltration system on which runoff infiltrates through a permeable layer or other stabilized permeable surface (Field and Tafuri [6]). Permeable pavements operate on runoff volume through retention, infiltration and possible reuse.

Another feature of interest on SUDs is water quality, considering that stormwater is related with non-punctual pollution which shows a more complex control and can often be the main source for streams pollution. Permeable pavement can affect the water quality through mechanisms of sedimentation, filtration, adsorption, biodegradation and volatilization promoting nutrient, sludge, heavy metals and hydrocarbons removal (Woods-Ballard et al. [5]).

Other aspects can also be incorporated into paving related with sustainability, as such water reuse (Pratt [9], Imran et al. [10]), water reuse for energy saving purposes (Sañudo-Fontaneda et al. [11]), temperature decreasing (Asaeda and Ca [12], Smith [13] and Sarat and Eusuf [14]) the combination with photocatalytic cement based pavements in order to reduce air pollutants (de Melo et al. [15]) and improve water quality (Tota-Maharaj and Scholz [16]).

\section{Definition and background}

Permeable pavements are defined as those having open spaces in its structure where water and air can pass through and can be used for roads, parking lots, courtyards, among others. The surface receives directly traffic load and must also allow water to infiltrate promptly. There are various surfaces available, such as: 
pre-cast concrete blocks, in placed porous concrete, porous asphalt, concrete grids, porous aggregates, grass, plastic grids, granular materials and loose decks (Ferguson [17]). The ones that provide vehicular support are the concrete blocks, used on permeable interlocking concrete pavement, porous concrete and porous asphalt. The pavement base/subbase is similar to a conventional one, the main difference being the aggregates void content, which must be such that allows the base to function as a water reservoir (Smith [18]). The high void content results on less strength, for that reason, permeable pavements are normally applied on areas with low volume traffic and with limited heavy vehicle loading (Hein et al. [19]).

Early studies on permeable pavements date from the 70 s and were mostly conducted on laboratory, normally using simulation rainfall (Pratt [20]). The first full-scale tests were held starting in the 80s (as shown in Table 1). Those studies mostly evaluated the efficiency of pavements on reducing runoff volume and pollutants removal testifying its effectiveness as SUDs, as well as confirming locally its availability.

\section{Runoff volume}

The primary role of a permeable pavement is to reduce runoff volume and promote hydrograph attenuation; therefore this feature was considered on the majority of researches. Recording the runoff for 11 storm events, Smith [13] obtained a range from 0.00 (zero) to 0.35 runoff coefficient for a parking lot with concrete grip pavers fill with grass while a impervious lot nearby resulted on 1.00 .

After the full scale tests held with porous asphalt by Hogland et al. [21], due to observed difficulties on cleaning, Pratt [22] tested concrete blocks for permeable interlocking concrete pavement on a full scale test held in Nottingham. Analyzing the hydrograph attenuation it was observed that the period of discharge was delayed by many hours after the rainfall, while on an impermeable pavement usually by them all the runoff is discharged. In one event, after the rainfall, $42 \%(9 \mathrm{~mm})$ of a 21.6 rainfall was discharged on the permeable pavement, for example. After a 30 days period it was observed a range of $55 \%$ to $75 \%$ runoff for the different bases. The same full scale test was addressed in Pratt et al. [23]) and shown a runoff average from $37 \%$ to $45 \%$, depending on base type, considering 62 rainfall events.

Using a rainfall simulator over permeable interlocking concrete pavement with porous concrete block; Suda et al. [24] observed that on a $50 \mathrm{~mm} / \mathrm{h}$ intensity rainfall, the water infiltrated without runoff for the first 30 minutes. On a field test the water infiltration was visually confirmed, although a reduction on permeability due to clogging after 6 months of use was observed. The type of surface can affect the pavement performance; Acioli [25] monitored a parking lot for a year and observed $5 \%$ of runoff on porous asphalt while $2.3 \%$ on concrete grids fill with grass. 


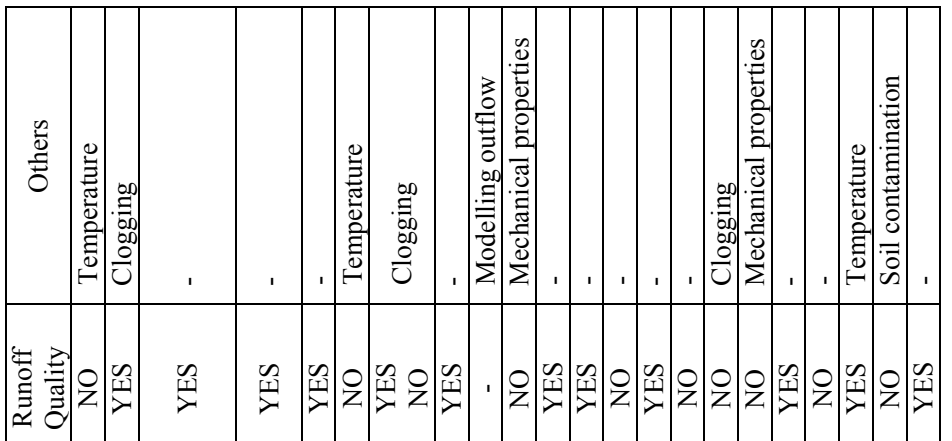

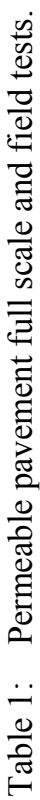

出

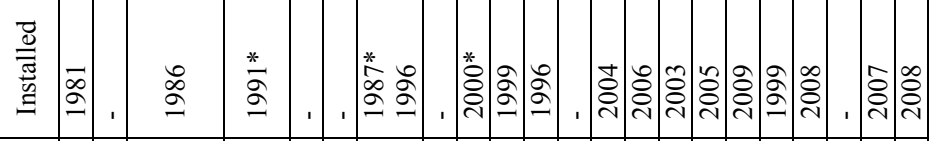

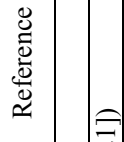

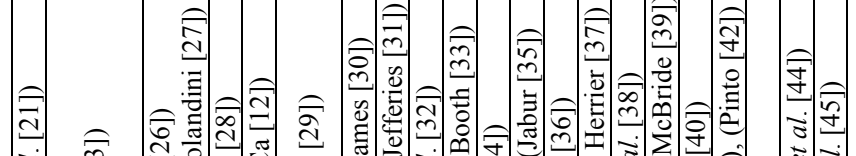

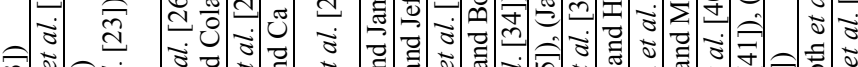

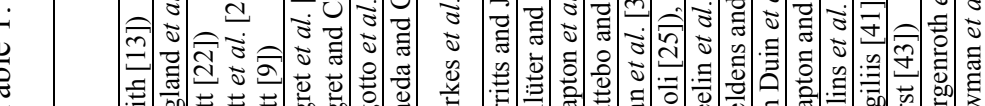

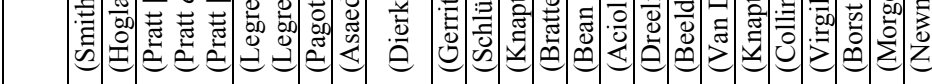

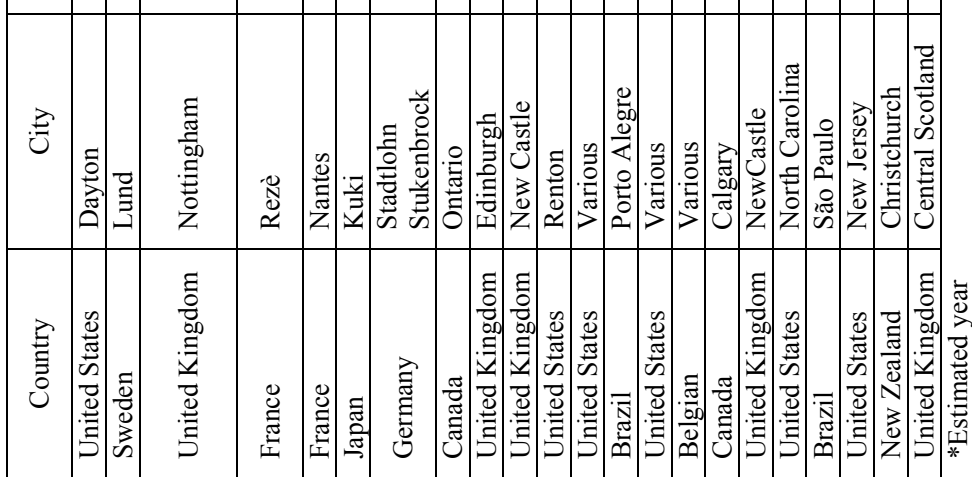


In Pagotto et al. [28] a porous asphalt pavement was observed for a year then compared to a conventional asphalt pavement previously installed on the same site. In this case the porous asphalt was installed over an impervious surface, therefore could not be considered a fully permeable pavement. Comparing the results, the flow volume was actually higher on the porous asphalt, with $7825 \mathrm{~m}^{3} /$ ha versus $5840 \mathrm{~m} 3 /$ ha on the conventional asphalt, and although the measurements were made on an one year gap it is possible to infer that the permeable base is essential to guarantee the reduction of runoff volume. On the other side, the response time mean, i.e., elapse time between the rain and the beginning of the flow, was higher on the porous asphalt (2:30 versus 1:15 on conventional asphalt) meaning that the system function on hydrograph attenuation. Besides the infiltration purposes, porous asphalt is often used for avoiding aquaplaning and water splashing, therefore reducing the risk of accidents and also for reducing noise, even if installed over a regular base (Pagotto et al. [28]).

Still regarding the base, Acioli [25] noticed that during the entire monitoring time the storage capacity of the base reservoir never exceed $25 \%$, meaning that the design method oversized the base thickness, which would be uneconomical. Also, in Pinto [42], the full capacity of the base reservoir wasn't reached, reassuring the importance of an accurate design method. The author enumerates the required information for designing a permeable pavement: existence of contribution area, precipitation data considering time of concentration and return period, base and surface material characteristics regarding void content and permeability, subgrade slope and if the pavement promotes full, partial or no infiltration on the subgrade. None of the design methods analyzed in Pinto [42] referred to all features.

The subgrade soil can also influence on the pavement's performance, as observed in Bean et al. [34]) that registered lower infiltration rate on permeable pavements over clay soils when compared with sandy soils. In order to attest the feasibility also on clay soils, Dreelin et al. [36] monitored for a year a pavement installed over this type of soil and it generated $93 \%$ less runoff than a reference conventional pavement. Also, in cases of low permeability subgrade the permeable pavement can include a drainage tube to outlet the water excess.

The full scale tests above were built mostly for research, while Beeldens and Herrier [37] monitored 50 sites of existing pavements up to 10 years of life using a double ring infiltrometer and found an acceptable overall performance on surface infiltration and storage capability, highlighting the importance of the base thickness and the subgrade soil infiltration rate.

The full scale and fields tests provide reliability on the systems and a natural second step was to develop models on the system's behavior providing tools for developers. Using the Erwin 3.0 rainfall-runoff model with adaptations, Schlüter and Jefferies [31] modelled the outflow volume on an existing permeable pavement on Edinburgh, Scotland achieving acceptable agreement for both peak flow and volume. The United States Environmental Protection Agency's Storm Water Management Model (SWMM) can be also used with this purpose of simulated the hydraulic response behavior in long-term applications for 
permeable pavements and was used by Qin et al. [46] to investigate the impact of SUDs on a China development and by Sansalone et al. [47] on a Florida development attesting the gains of applying permeable pavement. On a review on models for sustainable drainage systems, Elliott and Trowsdale [7] found 40 models and analyzed 10 that were available and with sufficient information. None of the models analyzed feature the full scope of the system and usually addressed planning preliminary design information. Therefore, although it is already available a range of models it still lacks on a broader tool that could easily help from planning to application of sustainable urban drainage systems.

\section{Runoff quality}

In Pratt [22], it was analyzed the short and long term variations in pollutants discharges, were four different stones used as base produced a range of quality discharges, i.e. $\mathrm{pH}$ and alkalinity could be reduced by using blast furnace slag, while reduction of hardness and lead discharge could be achieved by using limestone. However, in long term, the stone variations were small, meaning limited chemical degradation. Analyzing suspended solid variations it was found a range from near 0 (zero) to $50 \mathrm{mg} / \mathrm{l}$ while on an impermeable pavement it can fluctuated from $30 \mathrm{mg} / 1$ to $300 \mathrm{mg} / \mathrm{l}$, with peaks of $1000 \mathrm{mg} / \mathrm{l}$, hence the permeable pavement not only shown reduced concentration of suspended solids but also greater stability. On the same study the four type bases were subjected to a 10 year rainfall laboratory simulation and it was analyzed fine sediments, organic material and lead accumulation through the layers of the pavement. With small variations the larger part of the output sediments were trapped above the geotextile, on the gravel layer.

The pollutants removal was also addressed by Legret et al. [26] using a porous asphalt surface, porous bitumen stabilized base, crushed stones sub-base and a geotextile above the subgrade. After analyzing about 30 rainfall events and comparing with a nearby impermeable pavement, the permeable pavement showed a decrease about $64 \%$ for suspended solids and $79 \%$ on lead. After 4 years, the structure of the pavement was analyzed revealing that the micropollutants tend to accumulate on the pervious asphalt and the geotextile level, not being observed contamination on the soil. The same test was analyzed in Legret and Colandini [27] observing also a reduction on the following pollution contaminants - suspended solids, $\mathrm{Pb}, \mathrm{Cu}, \mathrm{Cd}$ and $\mathrm{Zn}-$ on the permeable pavement discharge. Samples extracted from the pavement structure and soil below shown that metal pollutants are mainly retained on the porous asphalt and the soil doesn't present contamination after the 8 years that the permeable pavement was operational.

The role of the geotextile on the pollutants removal has then been discussed in Kirkpatrick et al. [48] where removal of hydrocarbons without the use of geotextile was achieved 93.1\%. In fact, in Dierkes et al. [29], the tests conducted with porous concrete interlocking pavement showed that most of the heavy metals were trapped on the upper layer of the porous concrete blocks, conclusion find also in Mullaney et al. [49] where up to $60 \%$ of the metals on a equivalent 
of 20 years of sediments were also trapped on the upper layers, with or without geotextile.

Instead of analyzing the water outflow, Morgenroth et al. [44] analyzed the soil below 25 sites being no pavement, conventional pavement and permeable pavement and discovered alterations on soil physical and chemical characterizes that could impact vegetation. According to Morgenroth et al. [44] permeable pavement can alter soil $\mathrm{pH}$ which affects soil solubility, reducing concentrations of $\mathrm{Al}, \mathrm{Fe}$ and $\mathrm{Mg}$ while increasing $\mathrm{Na}$ concentration. The effect will depend upon the soil initial conditions.

Although the studies already mentioned focus on more traditional stormwater pollutants, the effect of microorganism must also be taken in account. For instance, faecal pollution can cause health risks by affecting water sources and economical loss by beaches closures (McCarthy et al. [50]). In Tota-Maharaj and Scholz [16], the use of an interlocking permeable pavement combined with titanium dioxide on laboratory experiment was able to completely remove from runoff Escherichia coli, total coliforms and faecal Streptococci through the photocatalytic reaction.

As from runoff volume, models were created to simulate the pollutants' removal on SUDs. Imteaz et al. [51] analyzed the accuracy of the Model of Urban Stormwater Improvement Conceptualization (MUSIC) by comparing with field measurements and observed that for permeable pavement the model overestimates the flow removal and consequently the pollutants removal, that in this case were suspended solids, Total Phosphorus and Total Nitrogenous. Therefore, the author suggests that the model still needs adjustments and for better accuracy a physically based deterministic model should be developed. Also, the already mentioned SWMM can be also used to model runoff quality (Kipkie [52], Sansalone et al. [47] and Qin et al. [46]).

\section{Design life and maintenance}

Even though permeable pavement showed acceptable performance on initials conditions a constant worried was its design life particularly due to clogging. After testing a number of pavements using an infiltrometer, Borgwardt [53] concluded that after 20 years a permeable pavement could lose $80 \%$ of its initial infiltration rate. Several studies (Pratt [22], Legret and Colandini [27], Dierkes et al. [29], Gerritts and James [30] and Mullaney et al. [49]) demonstrate that sediments are usually trapped on the upper layers, thus remedial work would concentrate there. In fact, Pratt [22] affirmed that paving blocks would show an advantage in maintenance, which consist in removing the joint material and bedding layer, while monolithic surfaces might require reinstallation. For instance, after 9 years of use, Jabur [35] conducted single-ring infiltrometer tests on the same pavement studied by Acioli [25], observing that the porous asphalt was almost fully clogged while the concrete grids was still function. Also, in a full scale experiment in Calgary, Canada, Van Duin et al. [38] observed that after 10 months of use the porous asphalt was completely clogged, probably due to the use of winter sand and traffic loads and even maintenance using vacuum 
sweeping couldn't increase infiltration. On the other hand, the portion of the pavement with permeable interlocking concrete pavement showed improvement after maintenance by removing the clogged joint material. The author commented that modification on the mix design of the porous asphalt could improve its performance.

In a field test conducted by Dierkes et al. [29] the infiltration capacity was measured using a drip-infiltrometer before and after cleaning using a high pressure cleaner with direct vacuum suction. Before remedial works all points showed a infiltration capacity below $1 \mathrm{~mm} /(\mathrm{s}$ ha), much lower than the $270 \mathrm{l} / \mathrm{(s} \mathrm{ha)} \mathrm{required} \mathrm{by} \mathrm{local} \mathrm{law.} \mathrm{However,} \mathrm{after} \mathrm{maintenance} \mathrm{the} \mathrm{infiltration}$ capacity reached values between $1545 \mathrm{l} /(\mathrm{s} \mathrm{ha})$ and $5276 \mathrm{l} /(\mathrm{s}$ ha) therefore comprising legislation. Using an adaptation of a soil infiltration test, the doublering infiltrometer Bean et al. [34] analyzed the surface infiltration on 27 pavements sites with ages ranging from 6 months to 20 years, on initial conditions and after maintenance. The average infiltration for permeable interlocking concrete pavement with enlarge joints was $8,0 \mathrm{~cm} / \mathrm{h}$ and after maintenance it reached average of $2000 \mathrm{~cm} / \mathrm{h}$ on sites without soil disturbance, while on the other case it reached average of $61 \mathrm{~cm} / \mathrm{h}$, punctuating the importance of the pavement adjacent.

To predict and reduce this process Yong et al. [54] analyze the physical mechanism of clogging, punctuating the need for further investigations and modeling of biological clogging both. Yong et al. [54] also affirm that the design has great relation with clogging comparing three surfaces being monolithic asphalt, monolithic aggregate and resign and interlocking concrete pavement.

\section{Conclusion}

Analyzing the literature it is possible to confirm the feasibility of permeable pavement as SUDs by effectively promoting runoff volume reduction and pollutants removal. However, in order to guarantee its properly performance is important to conceive the entire structure permeable, providing surface material with proper infiltration rate, an open graded base and observed the subgrade soil features regarding the infiltration rate and also use an accurate pavement design considering mechanical and hydrological features. The base should have a high void content, therefore behaves as a reservoir, but still providing the necessary mechanical strength. Even though clogging may occur, through maintenance the pavement can regain acceptable infiltration rates. To extend the design life it is important to guarantee the characteristics of the surface layer and observe the adjacent areas. There are already a number of SUDs models that comprises permeable pavement, but it stills lacks a broader tool comprising all the main aspects of the system, as outflow volume, pollutants removal, mechanical performance and design life aspects. In conclusion, permeable pavement can be a feasible solution for urban drainage and its use should be encouraged. Although the system is fully available for commercial use research is undergoing to improve specific points. 


\section{References}

[1] Heilig, G. K., "World Urbanization Prospects: The 2011 Revision," United Nations, Department of Economic and Social Affairs (DESA), Population Division, Population Estimates and Projections Section, New York, 2012.

[2] USEPA Urbanization and Streams: Studies of Hydrologic Impacts: U.S. Environmental Protection Agency, Office of Water, 1997.

[3] Alves Filho, A. P., and Ribeiro, H., "Configuração Espacial de eventos de precipitação extrema na Região Metropolitana de São Paulo: interações entre a ilha de calor e a entrada da brisa oceânica.," InterfacEHS, vol. 2, pp. 1-8, 2007.

[4] Paulo, S., "Manual de Drenagem e manejo de águas pluviais: gerenciamendo do sistema de drenagem urbana.," S. M. d. D. U. (SMDU), ed., 2012, p. 168.

[5] Woods-Ballard, B., Kellagher, R., Martin, P., Jefferies, C., Bray, R., and Shaffer, P., The SUDS manual (C697): CIRIA, 2007.

[6] Field, R., and Tafuri, A. N., The Use of Best Management Practices (BMPs) in Urban Watersheds: DEStech Publications, 2006.

[7] Elliott, A. H., and Trowsdale, S. A., "A review of models for low impact urban stormwater drainage," Environmental Modelling \& Software, vol. 22, no. 3, pp. 394-405, 2007.

[8] Paulo, S., "Manual de Drenagem e manejo de águas pluviais: aspectos tecnológicos, diretrizes para projetos.," S. M. d. D. U. (SMDU), ed., 2012, p. 128.

[9] Pratt, C. J., "Use of permeable, reservoir pavement constructions for stormwater treatment and storage for re-use," Water Science and Technology, vol. 39, no. 5, pp. 145-151, 1999.

[10] Imran, H. M., Akib, S., and Karim, M. R., "Permeable pavement and stormwater management systems: a review," Environmental Technology, vol. 34, no. 18, pp. 2649-2656, 2013/09/01, 2013.

[11] Sañudo-Fontaneda, L., Castro-Fresno, D., Rodriguez-Hernandez, J., and Borinaga-Treviño, R., "Comparison of the Infiltration Capacity of Permeable Surfaces for Rainwater Energy Valorization."

[12] Asaeda, T., and Ca, V. T., "Characteristics of permeable pavement during hot summer weather and impact on the thermal environment," Building and Environment, vol. 35, no. 4, pp. 363-375, 2000.

[13] Smith, D. R., "Evaluations of concrete grid pavements in the United States." p. 7.

[14] Sarat, A.-A., and Eusuf, M. A., "Effects of pavement surface temperature on the modification of urban thermal environment," DIMENSI (Jurnal Teknik Arsitektur), vol. 39, no. 1, pp. 1-4, 2012.

[15] de Melo, J. V. S., Trichês, G., Gleize, P. J. P., and Villena, J., "Development and evaluation of the efficiency of photocatalytic pavement blocks in the laboratory and after one year in the field," Construction and Building Materials, vol. 37, no. 0, pp. 310-319, 12, 2012. 
[16] Tota-Maharaj, K., and Scholz, M., "Combined permeable pavement and photocatalytic titanium dioxide oxidation system for urban run-off treatment and disinfection," Water and Environment Journal, vol. 27, no. 3, pp. 338-347, 2013.

[17] Ferguson, B. K., Porous Pavements: Taylor \& Francis, 2005.

[18] Smith, D. R., "Permeable Interlocking Concrete Pavements," America: ICPI, 2000.

[19] Hein, D. K., Swan, D., and Schaus, L., "Structural and hydrological design of permeable pavements." p. 20.

[20] Pratt, C. J., "Sustainable drainage: A review of published material on the performance of various SUDS components," Prepared for the Environment Agency. SUDS Science Group/99705.015, 2004.

[21] Hogland, W., Niemczynowicz, J., and Wajlman, T., "The unit superstructure during the construction period," Science of the Total Environment, vol. 59, pp. 411-424, 1987.

[22] Pratt, C. J., "Permeable pavements for stormwater quality enhancement." pp. 131-155.

[23] Pratt, C. J., Mantle, J., and Schofield, P., "UK research into the performance of permeable pavement, reservoir structures in controlling stormwater discharge quantity and quality," Water science and technology, vol. 32, no. 1, pp. 63-69, 1995.

[24] Suda, S., Yamanaka, S., Hata, M., and Kunimura, T., "Development and application of permeable paving concrete block."

[25] Acioli, L. A., "Estudo experimental de pavimentos permeaveis para o controle de escoamento superficial na fonte," Recursos Hidricos e Saneamento Ambiental, Universidade Federeal do Rio Grande do Sul, Porto Alegre, 2005.

[26] Legret, M., Colandini, V., and Le Marc, C., "Effects of a porous pavement with reservoir structure on the quality of runoff water and soil," Science of The Total Environment, vol. 189-190, no. 0, pp. 335-340, 1996.

[27] Legret, M., and Colandini, V., "Effects of a porous pavement with reservoir structure on runoff water: Water quality and fate of heavy metals," Water Science and Technology, vol. 39, no. 2, pp. 111-117, 1999.

[28] Pagotto, C., Legret, M., and Le Cloirec, P., "Comparison of the hydraulic behaviour and the quality of highway runoff water according to the type of pavement," Water Research, vol. 34, no. 18, pp. 4446-4454, 2000.

[29] Dierkes, C., Kuhlmann, L., Kandasamy, J., and Angelis, G., "Pollution retention capability and maintenance of permeable pavements."

[30] Gerritts, C., and James, W., "Restoration of infiltration capacity of permeable pavers."

[31] Schlüter, W., and Jefferies, C., "Modelling the outflow from a porous pavement," Urban Water, vol. 4, no. 3, pp. 245-253, 2002.

[32] Knapton, J., Cook, I. D., and Morrell, D., "A new design method for permeable pavements surface with pavers.," Highway Engineer from The Institution of Highways \& Transportation, no. February, 2002. 
[33] Brattebo, B. O., and Booth, D. B., "Long-term stormwater quantity and quality performance of permeable pavement systems," Water Research, vol. 37, no. 18, pp. 4369-4376, 2003.

[34] Bean, E. Z., Hunt, W. F., Bidelspach, D. A., and Smith, J., "Study on the surface infiltration rate of permeable pavements," Proceedings of the American Society of Civil Engineers and EWRI 2004 world water and environmental resources congress, Salt Lake City, UT, USA, vol. 27, 2004.

[35] Jabur, A. S., Relatório final de pós-doutorado Universidade Federal do Rio Grande do Sul, 2013.

[36] Dreelin, E. A., Fowler, L., and Ronald Carroll, C., "A test of porous pavement effectiveness on clay soils during natural storm events," Water Research, vol. 40, no. 4, pp. 799-805, 2006.

[37] Beeldens, A., and Herrier, G., "Water pervious pavement blocks: the belgian experience."

[38] Van Duin, B., Brown, C., Chu, A., Marsalek, J., and Valeo, C., "Characterization of long-term solids removal and clogging processes in two types of permeable pavement under cold climate conditions." pp. 1-10.

[39] Knapton, J., and McBride, C., "Permeable pavements for heavily trafficked roads - a full scale trial." pp. 1-10.

[40] Collins, K. A., Hunt, W. F., and Hathaway, J. M., "Evaluation of various types of permeable pavements with respect to water quality improvement and flood control."

[41] Virgiliis, A. L. C. d., "Procedimentos de projeto e execução de pavimentos permeáveis visando retenção e amortecimento de picos de cheias.," Escola Politécnica - Engenharia de Transportes, Universidade de São Paulo, São Paulo, 2009.

[42] Pinto, L. L. C. A., "O desempenho de pavimentos permeáveis como medida mitigadora da impermeabilização do solo urbano.," Escola Politécnica - Engenharia de Transportes, Universidade de São Paulo, São Paulo, 2011.

[43] Borst, M., Surface infiltration rates of permeable surfaces: Six month update (November 2009 through April 2010): National Risk Management Research Laboratory, Water Supply and Water Resources Division, US Environmental Protection Agency, 2010.

[44] Morgenroth, J., Buchan, G., and Scharenbroch, B. C., "Belowground effects of porous pavements - Soil moisture and chemical properties," Ecological Engineering, vol. 51, no. 0, pp. 221-228, 2013.

[45] Newman, A. P., Aitken, D., and Antizar-Ladislao, B., "Stormwater quality performance of a macro-pervious pavement car park installation equipped with channel drain based oil and silt retention devices," Water Research, vol. 47, no. 20, pp. 7327-7336, 2013.

[46] Qin, H.-p., Li, Z.-X., and Fu, G., "The effects of low impact development on urban flooding under different rainfall characteristics," Journal of Environmental Management, vol. 129, no. 0, pp. 577-585, 2013.

[47] Sansalone, J., Raje, S., Kertesz, R., Maccarone, K., Seltzer, K., Siminari, M., Simms, P., and Wood, B., "Retrofitting impervious urban infrastructure 
with green technology for rainfall-runoff restoration, indirect reuse and pollution load reduction," Environmental Pollution, vol. 183, no. 0, pp. 204-212, 2013.

[48] Kirkpatrick, R., Campbell, R., Smyth, J., Murtagh, J., and Knapton, J., "Improvement Of Water Quality By Coarse Graded Aggregates In Permeable Pavements." p. 3.

[49] Mullaney, J., Rikalainen, P., and Jefferies, C., "Pollution profiling and particle size distribution within permeable paving units-with and without a geotextile," Management of Environmental Quality: An International Journal, vol. 23, no. 2, pp. 150-162, 2012.

[50] McCarthy, D. T., Hathaway, J. M., Hunt, W. F., and Deletic, A., "Intraevent variability of Escherichia coli and total suspended solids in urban stormwater runoff," Water Research, vol. 46, no. 20, pp. 6661-6670, 2012.

[51] Imteaz, M. A., Ahsan, A., Rahman, A., and Mekanik, F., "Modelling stormwater treatment systems using MUSIC: Accuracy," Resources, Conservation and Recycling, vol. 71, no. 0, pp. 15-21, 2013.

[52] Kipkie, C., "Feasibility of a permeable pavement option in the storm water management model (SWMM) for long term continuous modelling," Master of Science Thesis, University of Guelph, 1998.

[53] Borgwardt, S., "Long-term in-situ infiltration performance of permeable concrete block pavement." pp. 6-8.

[54] Yong, C. F., McCarthy, D. T., and Deletic, A., "Predicting physical clogging of porous and permeable pavements," Journal of Hydrology, vol. 481, pp. 48-55, 2013. 